\title{
Statyba
}

\section{ANALYSIS OF LIFE-TIME PROCESS OF A BUILDING}

\section{A. Kaklauskas}

To cite this article: A. Kaklauskas (1996) ANALYSIS OF LIFE-TIME PROCESS OF A BUILDING, Statyba, 2:6, 33-43, DOI: 10.1080/13921525.1996.10531642

To link to this article: https://doi.org/10.1080/13921525.1996.10531642

册 Published online: 26 Jul 2012.

Submit your article to this journal $\pi$

III Article views: 41

4 Citing articles: 1 View citing articles 진 


\section{ANALYSIS OF LIFE-TIME PROCESS OF A BUILDING}

\section{A. Kaklauskas}

\section{General layout of life-time process of a building}

It is obvious, that in order to design and realize a high-quality project, it is necessary to take care of its efficiency from the brief to the end of maintenance. The entire process must he planned and executed with consideration of goals aspired by participating interested partics. A proposed general layout is given in Fig. 1. The layout shows that by using methods of alternative designing and multicriteria assessment it is possible rationally to plan and realize a project and all processes and decisions connected with it and at the same time to ensure maximum satisfaction of goals pursued by all interested parties involved in the process (Fig. 1).

Having transformed life-time process of the project into mathematical language, it can be cxpressed as transformation of required resources into the end production (Fig. 2). The project is realized in four main stages: brief, designing, construction and maintenance.

In the processes of brief, designing, construction and maintenance, the most attention is paid to the goals of the customer. First of all, it is necessary to perform a thorough clear-up of customer's demands and goals, and then - to express them through a system of criteria. Further, this system of criteria must be transformed into a language characteristic for the processes of brief, designing, construction and maintenance and introduced into these processes. In designing processes, this is expressed by calculations, various drawings (plans of the whole building, sections, etc.), specifications and the like.

Further follows a brief analysis of some life-time process stages of a building. Most attention is paid to quality increase possibilities.

Marketing specialists of an organization (designing, constructing, supplying) are watching the level of demand and supply for their production on the market and investigating the goals of potential customers. It concerns all processes related to the total quality of the building. Customer's solvency or capability to pay for the satisfaction of his various needs is also investigated. This information is very important when determining capability of an investigated organization to realize possible projects. Thorough and objective market investigation makes prerequisites for quality realization of the analysed projects in the future.

The planning of life-time process of a building is performed with constant consideration of goals set in the marketing stage. During this process, taking into account requirements presented by the customer and capabilities of designing, construction organizations and suppliers, goes on creation of the project itself. The designing and planning procedure must include multicriteria optimization not only of separate processes and decisions, but also of the whole life-time process of the building with coordination of needs expressed by all interested parties. Infcrior project version and various inaccuracies left over lessen overall quality of the project.

The level of project drawings and specifications must ensure a straight-forward construction. Therefore, designers, when solving essential designing problems, must coordinate their actions with constructors in order to create all conditions for effective execution of construction operations (ensured possibility to use efficient cranes, mechanisms, equipment, technologies, work methods, etc.)

Resources and means required for project realization (various technologies, organizing and material interest stimulating methods, structures, matcrials, workers, mechanisms, etc.) are selected basing oneself on criteria system reflecting their utility de- 


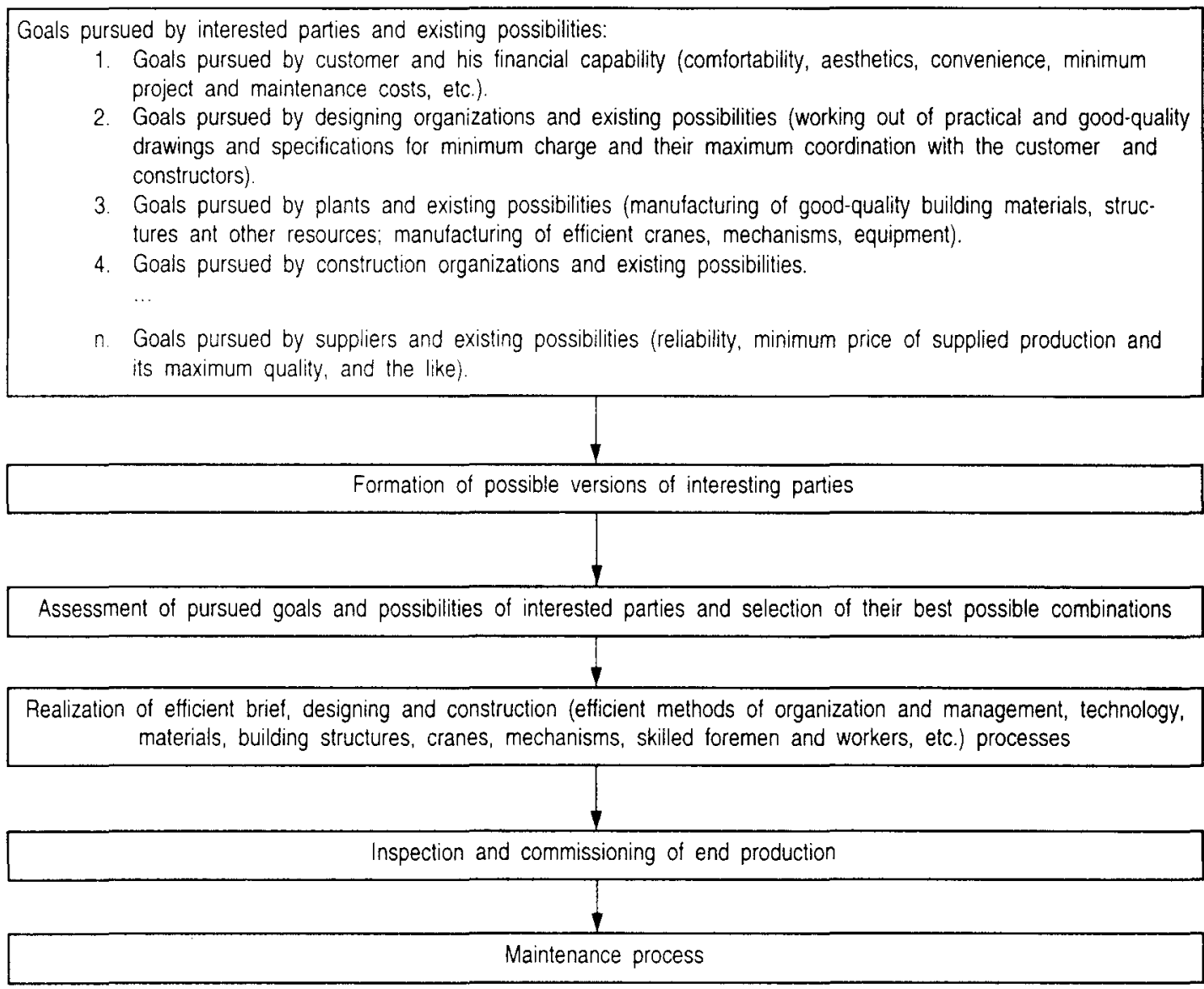

Fig. 1. General life-time process layout of a building

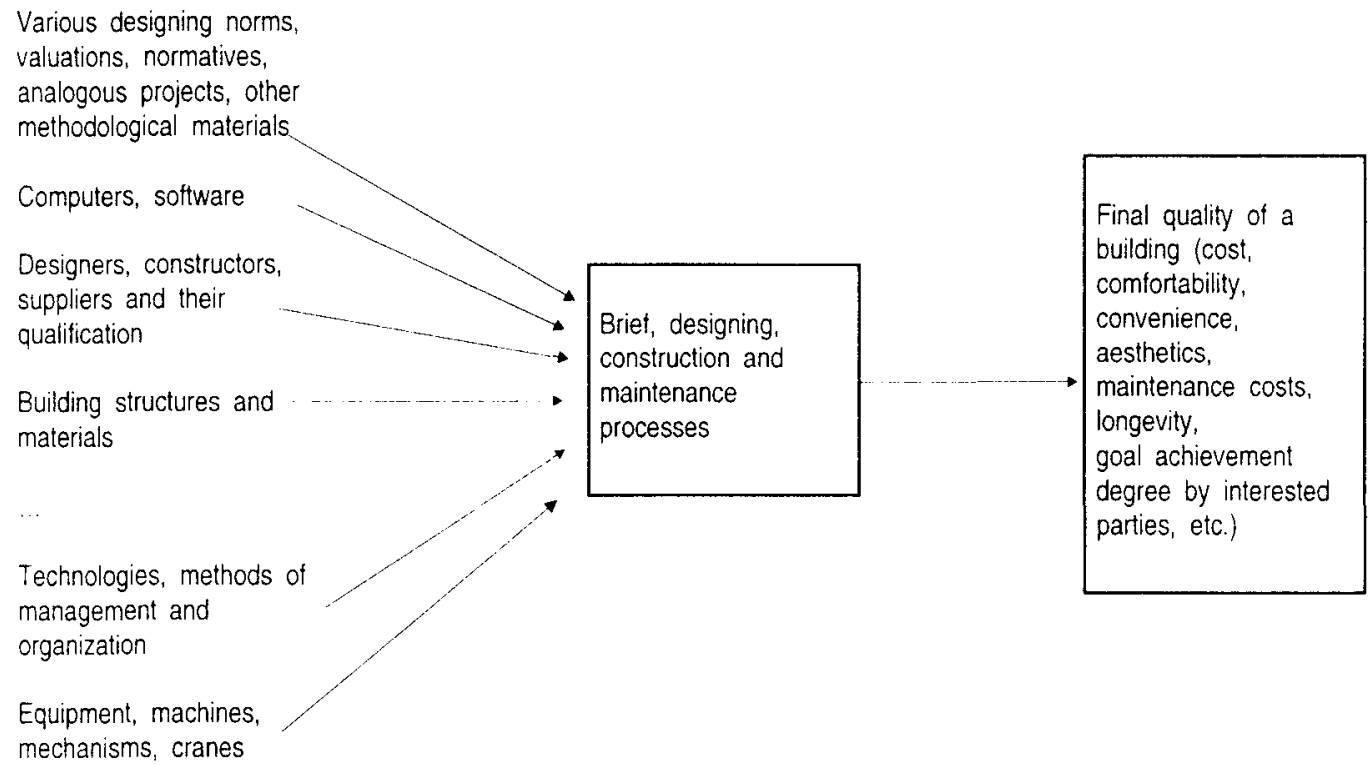

Fig. 2. Transformation of input resources into high-quality buildings 
gree. The required resources must be in maximum conformity with the requirements of life-time process of the building. For this, it is very important to pick rational suppliers. They must meet many requirements, for instance, to be reliable (to observe as accurately as possibic the conditions set in contract), to be capable to take care that the supplied resources are competitive, to be able and can be trusted to make necessary alterations in supplying process if such are required by changes in the project.

The quality of used resources and means (equipment, cranes, tools, structures, materials, etc.) must meel all presented requirements. They must be delivered in proper time to a predetermined place and be ready at hand for the execution of concrete jobs or processes. Quite often, poor working quality is a result of working in a hurry. This is often caused by bad planning, inaccurate job execution (delivery) schedules and by non-observance of set schedules. Firm resolution to finish all jobs in due time is one of essential sources for the increase of construction process quality.

Accurate control of labour, materials, structures, mechanisms and other resources and their effective use is an indispensable condition of high construction process level. Quality level of a construction process also depends quite a lot on good and business-like relations among participants of the process (site manager, work superintendents, foremen, teamlcaders, workers).

The efficiency of performed work also very much depends on quality level, physical wear-out and moral longevity of used cranes, mechanisms and tools. In other words, the quality of construction process closely depends on other industrial enterprises connected with construction (extraction and processing of raw materials; manufacturing of cranes mechanisms and tools). Everything is closely interconnected. For instance, using poor quality check equipment, the person checking quality of performed work will reccive inaccurate information, and, in such conditions, the required quality of work will never be achieved.

The quality of pre-labricated structures, materials as well as of other resources must be checked. It must be determined whether the turned out production is in conformity with set requirements, free of concealed defects which could reveal themselves later.
Such is the way to protect users from possible unpleasant future surprises. The articles must be properly packed, loaded, transported, unloaded and stored. Not rare are cases when some resources due to our climatic conditions and inferior labour culture are damaged just because the above-mentioned operations are carried out improperly.

New requirements appear when the construction object is completed and commissioned. They refer to proper maintenance of the building. The tenants must be instructed on main regulations. Observation of these regulations ensures maximum preservation of building's quality.

The factors mentioned above are directly connected with project quality increase process. But this is not sufficient in order to ensure high quality of a building. A lot of additional factors (economic capabilities, human relations, passed laws, etc.) must be taken into consideration (Fig. 4).

Economic capabilities should be such, that all necessary measures ensuring the desired project quality level could receive financial support. It is possible to calculate the cost of separate measures ensuring project quality and effect received from their implementation. Therefore, the most effective measures can be used for the ensuring of project quality (Fig. 3).

Quality control should be performed by a sufficiently skilled specialist. Besides, he should have an interest to carry out the entrusted job well and in good time. Very important is professional skill of specialists and good business-like relations of all interested parties involved in the life-time process of a building.

The life-time process of building is regulated by specific laws, norms and regulations which ought to be observed. This rather wide sphere includes signing of contracts, labour protection, observance of various obligations, etc.

\section{Interested parties}

\subsection{Analysis of interested parties}

The trend of activities and efficiency of various interested parties depend to a great extent on goals pursued by them. For instance, construction workers and civil engineers of the former Soviet Union in search of better earnings used to go to work in Si- 


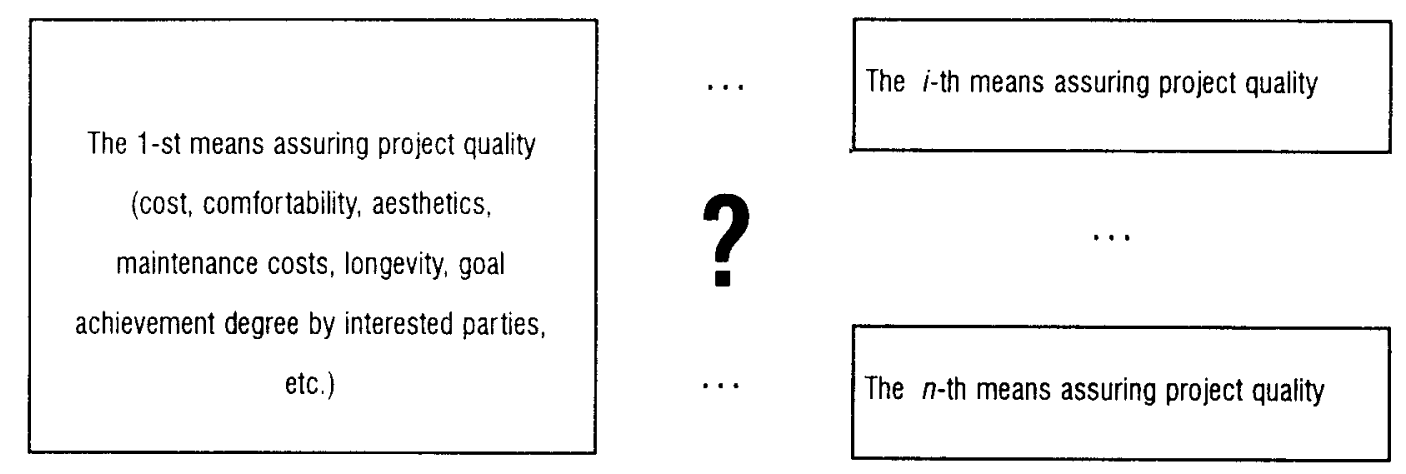

Fig. 3. Selection of efficient means assuring required quality level of a building in its life-time process

Typical interested parties, exerting influence on total quality of life-time process of a project:

government;

society; media;

customers:

contractors; designing organizations; suppliers; competitors; shareholders; employees of various organizations; neighbours:

other interesting parties

\section{Processes and decisions influencing the total quality of life-time process of a building:}

- existing laws in the field of construction industry;

- economy (level of demand and supply, credit receiving possibilities, fluctuation of national currency);

- local infrastructure;

- location of construction (ground lot price, existing communication facilities, shopping, transport and relaxation possibilities, neighbours);

- designing process (the goals pursued by various interested parties make up one entity);

- construction process (minimum costs and duration of construction, top quality aspirations and other goals of interested parties);

- maintenance process (maintenance costs of a building);

- quality of a building (comfortability, aesthetics, functional comfort);

- other processes and decisions.

Fig. 4. Factors influencing the total quality of life-time process of a building beria where work and relaxation conditions are not of the best. In this case, the builders for many reasons just wanted to earn more money, and the satisfaction of any other needs could never fully compensate the primary goal. There are more similar examples proving the widely known truth that a human being can seldom at once achieve all wanted goals connected with their economic, aesthetic, moral well-being, comfortability, etc. In most cases compromises are made by selecting the more urgent and more easily attainable goals at present and in the future. Therefore, persons, striving to earn more money, have to work in a concrete field where the demand is exceeded by the supply to the utmost. If they want to do an interesting job in the company of interesting people, they must look for an other field of activities. In other words, the quality of projects in great extent depends on the system of goals pursued by the participating interested parties. When the goals are changing, so the imaginary total quality degree of the same project is changing as well. Therefore, the interested parties, when drawing up the system of their goals, must know very precisely what are they striving at. A system of criteria fully reflecting the pursued goals is elaborated for 
their mathematical expression and, hence, for the calculation of criteria values and significances. Therefore, this subsection will look into interested parties, their goals and system of criteria reflecting the quality of projects.

One of the main tasks efficient implementation of a project is multicriteria optimization of its full life-time process with the aim of maximum satisfaction of purposes of all interested parties involved in the process.

The number of interested parties, their pursued goals and existing capacity can undergo changes caused by the type, extent and other factors of the project being realized. However, there exist typical interested parties with their typical pursued goals which very often determine the quality of a project. Some of them are named below $[2,3]$ :

- government (regional aid policies, regulation of competition, preferential credits, concessions on taxation, governmental orders);

- influence of society (ethics of work (giving or accepting of a bribe, team relations), conditions of work, the need of working places in various regions, taxes);

- media (various positive or negative articles about interested parties or services proposed by them, various advertising activitics);

- customers (maximum satisfaction of various needs in conditions of existing possibilities);

- designing organizations;

- contractors;

- competitors;

- distributors;

- suppliers (the list of supplied resources, their price and quality);

- employees of various organizations (level of earnings, bonus pay, satisfaction with work, its prestige and future outlooks, possibilities of unemployment, communication possibilities);

- shareholders (annual dividends, increasing the value of their investment in the company as the share price increases, the degree of risk, outlooks for the future);

- neighbours (aesthetics of a building, likes and dislikes between tenants of a new build- ing and those dwelling in existing buildings);

- other interested parties.

Life-time process of a project cannot be effectively implemented without the satisfaction of purposes of all interested parties (buyers, customers, constructing and designing organizations, suppliers, the Law and State bodies, the users, and so on). Some of the interested parties are briefly discussed below.

In the dictionary sense 'customers' usually means those who buy from us, that is, clients. Our use of the word 'customer' includes clients, but we go further. We stretch the word 'customers' to include all persons who are impacted by our processes and our products. Those persons include internal as well as external customers. The term 'external customer' is used here to mean persons who are not a part of our company but who are impacted by our products (clients, owners, the madia, the local communities, government regulatory bodies, the public). In a large company there are a lot of internal customers. We saw some examples on The Spiral, where internal departments are customers of other internal departments [1].

The standpoint of the State regarding specific activities (various laws and decisions, work of State institutions, etc.) makes a considerable influence on the activities of organizations. Bilateral interrelations between a customer and a constructor in many cases get into the sphere of relations governed by law. Every constructing organization has a certain status defined by the law. This status determines how the organization can carry out its activities and what taxes has to pay. However, some laws are not only very complicated, but are also not distinguished by any greater expediency.

Principal purpose of all organizations is maximum satisfaction of user's nceds and parallel realization of its own goals. In other words, ability of an organization to survive and to develop itself depends upon its ability to find a user in the sphere of own interests and to satisfy the user's requirements. The users, by means of deciding what goods and services are desirable to them for the wanted price, set the most effective direction of development for competing organizations, taking into account the results of their activity. In this case, the needs of users are satisfied, and this fact makes a decisive influence on the interrelations between constructors, suppliers and 
other interested parties.

Competitors are a very significant external factor. Their mutual influence on one another is very great. The management of every enterprise understands very well that if it will not satisfy the requirements of users as efficiently, as it is done by competitors, the enterprise will not hold out for long. In many cases, what production and for what price can be sold is set not by the users, but just by competition level. The users are not the single competition object of an organization. Competitive struggle can go on also for labour resources, materials, capital and the right to benefit from innovations. Such internal factors as working conditions, pay and mutual relations between chief and subordinate depend on competition level as well.

The selection of some interested parties (designing or constructing organizations, etc.) is done by competition. The customer then carries on negotiations with the interested parties selected by competition. During the talks, the interested parties must identify the fields of correspondence and non-correspondence of their interests. Having defined these fields, they must discover the cause of this incompatibility of interests. The methods of multicriteria planning and assessment could be used for successful solution of this conflict.

The interested parties and their aspired goals, briefly mentioned above, make up one entity. The greater is the scope of realization of pursued goals (taking into account their significance), the greater, in opinion of interested parties, is the total quality of the project. In other words, the total quality of a project is directly proportional to the entity of realized goals.

\subsection{Multicriteria analysis of interested parties' goals and strategies}

Earlier we were discussing life-time process quality of a building and its dependence on various decisions, processes and interested parties exerting influence on a project. However, in order to make a good job, when planning and realizing life-time process of a building, and to achieve maximum satisfaction of goals of all interested parties, it is necessary to perform their optimization striving for the best complex result and, at the same time, selecting the most efficient strategy. Further on, these problems will be looked into on an example of an organiza- tion. The principles laid out here partly apply to other interested parties as well.

\subsubsection{Goal setting of an organization}

Each organization (designing, constructing, supplying, etc.), like each of its members, makes attempts to reach at the same time a number of goals (economic, moral, legal, etc.). Some of them are easy attainable, some can be attained with difficulty. Also, they are not equally significant. Therefore, the interested parties, even if they fail to reach all the desired goals, but attain the sufficiently important ones, can feel quite contented with the situation. In this case, it is very useful to apply the principle of mutual substitution and summary satisfaction of needs (Fig. 5).

It is very difficult to give an objective formulation of the desired goals as nearly all members of an interested group have their own views. The use of expert and multicriteria methods can make this process somewhat more objective. The goals of an organization can be realized effectively only in the case when they are fomulated correctly, clearly and without any ambiguities, and the employees well informed about them. This increases their personal interest in what they do. The success of an establishment greatly depends on means and ways of its goal realization and on the extent to which they correspond to environment and wishes of interested parties to take part in it.

In order to increase the efficiency of organizations, it is necessary to improve system-oriented way of thinking of their employees. A lesson can be learned from decisions of the past. Experience enables an organization to correctly adjust the direction of its activities, to work with higher professional skill and to make effective forecasts for the future. In selecting separate elements of enterprise activities and treating all activities as a complex wholeness, one has to bear in mind the dynamic nature of environment and of the organization itself. This considerably hampers the analysis of this complex process.

General goals of an enterprise are formed and gradually settle down on the base of certain values and aims accepted in the organization as orientational. The pursued goals are described by certain characteristics [5]. 


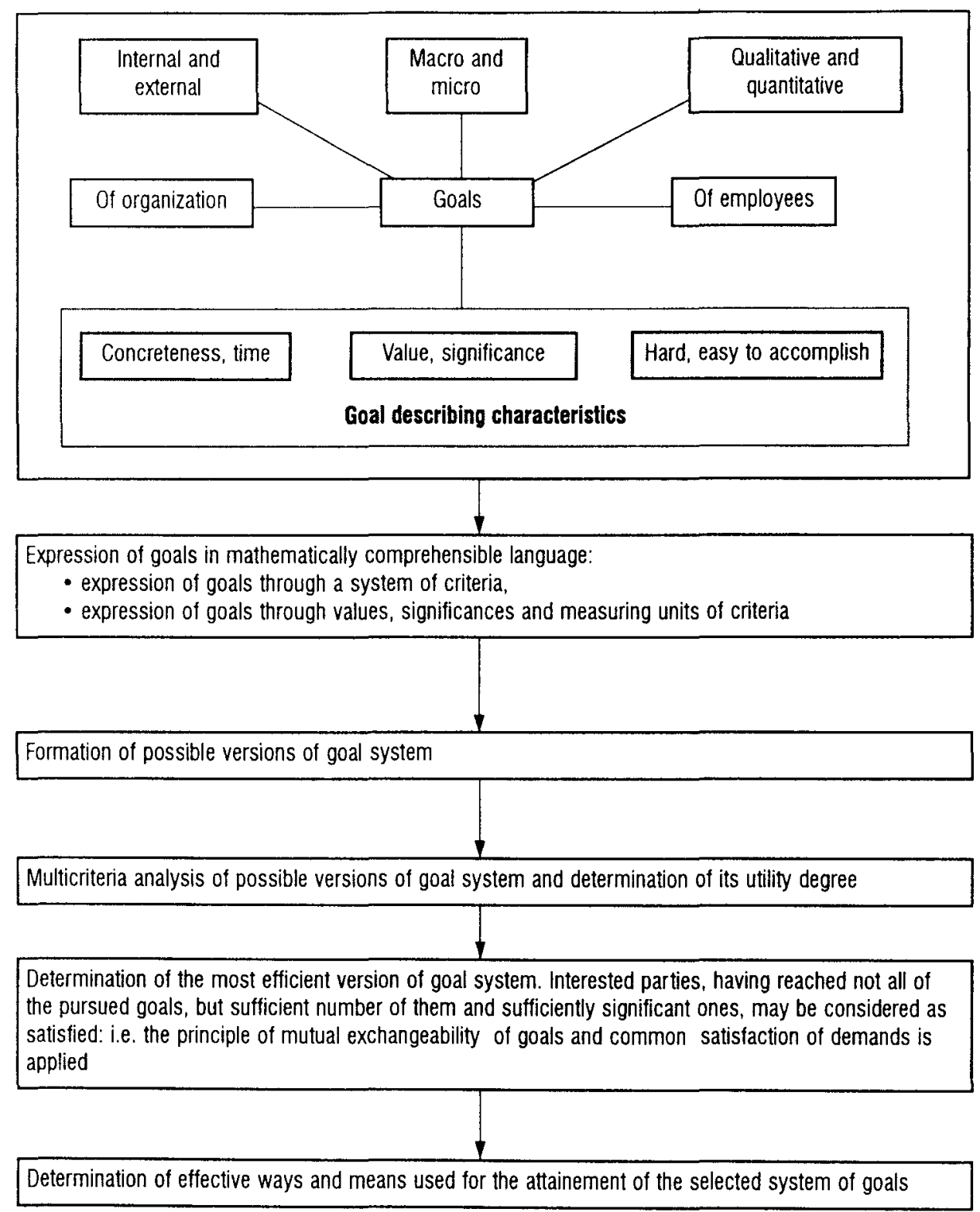

Fig. 5. General diagram for the optimization of goals of an enterprise

First of all, the goals should be specific. They should be expressed in numbers. Some organizations (designing, constructing, supplying, etc.) regard the satisfaction of their employees' needs as one of their main goals. Efforts are made, for instance, to increase the satisfaction of own employees with their job by $10 \%$ per year, to promote $15 \%$ of employees per year, to cut down the fluctuation of personnel by $10 \%$ per year. Such concrete numbers quite accurately inform the personnel about future outlooks. Expressing its attitude by concrete criteria, the organization creates an excellent base for mutual interest and settlement. In this case, the middle-rank managers will be equipped with a good guide for the solution of various problems (is there a necessity to increase efforts for the training and education of workers, or should the efforts be directed somewhere else, etc.). This would also facilitate the determination of degree by which goals of the organization had been realized and what effect did it have on organization's efficiency. When final results are known, actual policy of the enterprise can be adjusted accordingly [5].

It should be exactly known not only what an 
organization wants to accomplish, but also when it should start doing it and when intermediate and final results should be available.

The pursuit of inpracticable goals, for instance, trying to realize projects which surpass the organization's capabilities or the environment (faulty legislation, too powerful competitors, unfavourable demand and supply ratio for offered production, and the like) is adverse, may cause undesirable consequences (Fig. 6). In addition, the level of goal realization by an organization also has an effect on human relations within the organization itself because future plans of the personnel are often closely connected with the goals of the organization. If certain goals of an organization are doomed to failure, some goals of the personnel also remain unrealized. Such failure diminishes future prospects of the personnel and weakens its motivation. To quote a universally known proverb, in everyday life everybody with the same stone thrown wishes to kill as many hares as possible. No denying that it is a great treat when at the same time you are well paid, your job is creative and enjoyable and, to top all this, you have excellent chances of promotion. Unrealized goals of employees can harm the organization itself. Weakened motivation of employees can even reduce competitive level of the organization.

\subsubsection{Multicriteria analysis of organizations' strategies}

Strategy of an enterprise reflects most accurately and in the clearest way the goals and objectives to be achieved. It points out the best ways for their implementation taking into account the existing circumstances and real possibilities. By means of multicriteria designing and assessment methods it is possible to choose an efficient strategy version and also to distribute the resources of an organization rationally, so that it can bring the most appropriate final results.

The strategy of an enterprise represents coordinated actions by which interested parties involved in the project realization process are pursuing their goals, trying not to infringe interests of the others.

The strategy of an enterprise is used to make

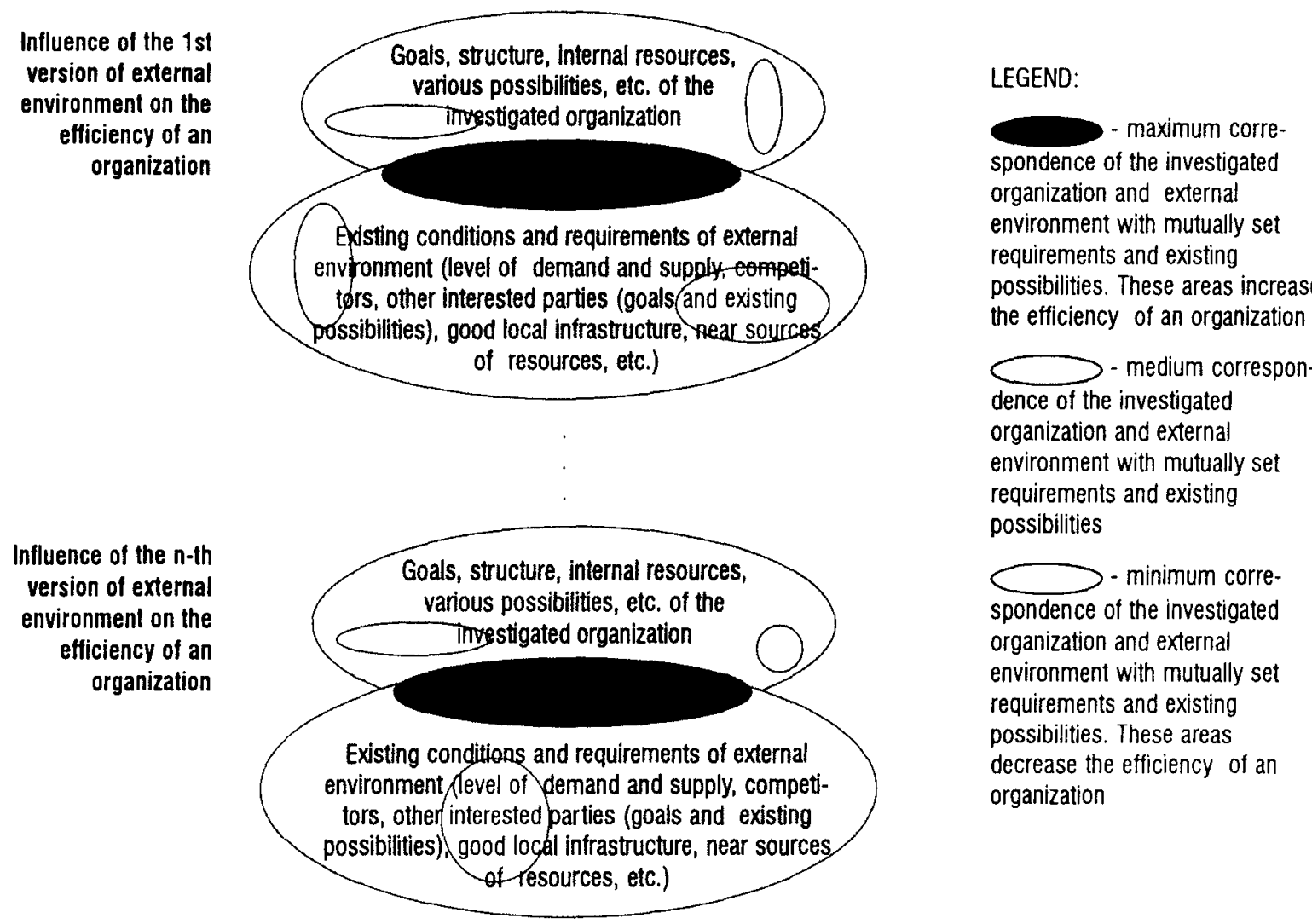

Fig. 6. Influence of possible versions of external environment on the efficiency of an organization 
management decisions and to realize projects observing the lines of rational policy. The strategy of an enterprise consists of several parts: allocation of resources, adaptation to environment, inside coordination, cte. [5].

The concept of adaptation should be understood in broad sense of the word. It involves all factors of strategic influence which improve the relations of an organization with all related interested partics. One of the major tasks of an organization is to carry out its activities under the most favourable conditions. In other words, efforts are made to ensure that the existing environmental conditions (convenient infrastructure of location, near sources of resources, positive demand and supply ratio, effective interested parties) would be in maximum conformity with the structure and goals of the organization. If the existing environment does not fully answer the wishes of interested parties, then they, basing themselves on their own goals and goals of other interested parties and taking into account certain values and aims prevailing in the organization, should make a compromise most acceptable for all parties.

The organizations should better search for realization markets in those spheres and geographical locations and with such interested parties where maximum satisfaction of goals of both sides could be granted. The most advanced organizations, therefore, strive to create the best conditions for their activities so that, ensuring the best satisfaction of clients' demands, they could earn better reputation and receive larger protit.

Inside coordination of an organization means rational management of its resources taking into account its goals and environment. In order to ensure an effective inside coordination of an organization, it is necessary to pay maximum heed to the advantages and shortcomings of the enterprise, to instill the achievements of advanced integration into the rational life-time process of a project [5].

An organization (designing, constructing, supplying, etc.), having performed the multicriteria alternative planning and assessment of its aspired goals and having picked the most rational version for certain existing internal resources and environment, herewith sets its strategy. At this stage the question "which way shall we go" is already answered. It is supposed that a knowledge base for multicriteria strategy plan- ning should be developed in the next stage. It could consist of the following parts:

- knowledge sheets characterizing the external environment;

- knowledge sheets characterizing the internal environment;

- knowledge sheets of possible combinations of interchangeable versions (Fig. 7).

And further, basing oneself on the presented knowledge sheets, all possible strategy versions are formed. Having formed the possible strategy versions, their multicriteria analysis is performed. When choosing a rational strategy, it is necessary to take into account all factors influencing its efficiency [3, 5]:

- risk (what risk degree is acceptable for the enterprise?). Risk is an inherent factor of an organization, but a high risk degree can ruin an enterprise;

- assessment of strategies realized earlicr. Very often, consciously or not, an organization feels the influence of strategies realized carlier;

- relations with labour team of the enterprisc;

- attitude in respect to the proprietor of the organization. Quite often the proprietor (share holders) restricts flexibility of the management in selecting of a certain strategic alternative;

- time factor. The time factor in decision making can be sometimes of decisive importance. Depending on situation formed inside and outside of an organization, a rationally made decision at one time can be quite unfit at another;

- assessment of competitors;

- assessment of other interested parties;

- the ratio of demand and supply;

- policy executed by the government, etc.

In most cases, an organization can choose one of the four principal alternative strategies (limited growth of the organization, growth, reduction, and also combinations of all these strategies). Each of these strategies has many versions [5].

An organization, wanting to expand the bounds of its present market, must carry out a detailed analysis of its competitive level, as compared with international. When an organization executes its projects not only in its own country, the planning of 


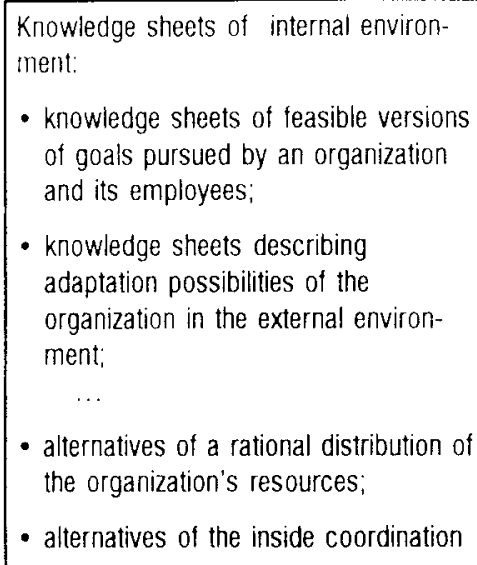

- knowledge sheets of feasible versions of goals pursued by an organization and its employees:

- knowledge sheets describing adaptation possibilities of the organization in the external environment;

- alternatives of a rational distribution of the organization's resources;

- alternatives of the inside coordination

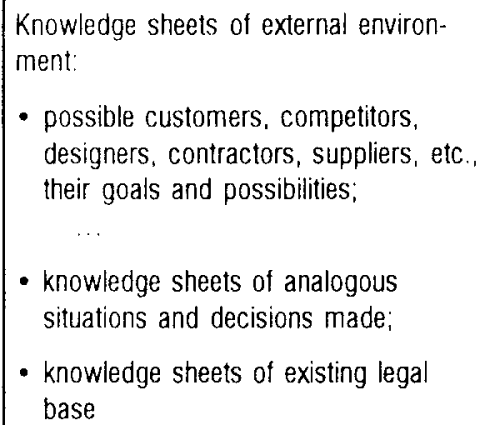

- knowledge sheets of analogous situations and decisions made;

- knowledge sheets of existing legal base

Fig. 7. Formation of feasible strategy versions of an organization

its future outlooks acquires a long-term complicity degree. Such an enterprise must not only analyse its possibilities, but it must carry out an analogous analysis in each country proposed for the realization of its projects. Efficiency level of these projects depends upon a number of factors:

- general strategy of the enterprise;

- economical, political, social and cultural development level of the country in question;

- demand and supply ratio of proposed production:

- capability of competitors;

- systems of taxes and customs;

- labour skill level;

- wages level;

- point of view of the community on foreign property;

- laws on labour and taxes;

- possibility to use local resources;

- transport costs [3, 5].

There are more factors than enumerated above that must be taken into account by an organization wanting to efficiently enter the market of other countries

\section{Reference}

1. M. Joseph. Juran on planning for quality. A Division of Macmillan, Inc. New York, 1988. 341 p.
2. J.L.Thompson. Strategic management. Awareness and change. Chapman and Hall, 1993.

3. E.Zavadskas, F.Peldschus, A.Kaklauskas. Multiple Criteria Evaluation of Projects in Construction / Institute of Technological and Economic Development (ITED), Vilnius Technical University. V.: Technika. 1994. $226 \mathrm{p}$

4. E.Zavadskas, A.Kaklauskas. Automated multivariant design of buildings, multi-purpose comprehensive evaluation and selection of the most efficient versions. Aalborg Universitetscenter, 1991. $65 \mathrm{p}$.

5. М. Х. Мескон, М. Альберт, Ф. Хедоури. Основы менеджмента: Пер. с англ. М.: Дело, 1992. 702 с.

İteikta $1996 \quad 03 \quad 05$

\section{SUINTERESUOTU GRUPIU ANALIZE}

\section{A. Kaklauskas}

\section{Reziumè}

Projekty efektyvumas labai priklauso nuo jame dalyvaujančių suinteresuoty grupiu siekiamų tikslų sistemos Keičiantis tikslams, keičiasi ir isivaizduojamas to paties projekto naudingumo laipsnis. Todel sudarant tiksly sistemą, suinteresuotos grupés labai tiksliai turi žinoti, ko jos sickia. Šiems poreikiams matematiškai aprašyti yra sudaroma kriterijų sistema pilnai atspindinti siekiamus tikslus bei apskaičiuojamos kriteriju reikšmés bei reikšmingumai. Šiame straipsnyje išnagrinetos suinteresuotos grupes, ju tikslai bei projektų efektyvumą atspindinti kriterijų sistema. 
Artūras KAKLAUSkas. Doctor, Associate Professor. Department of Building Technology and Management. Vilnius Technical University, 11 Saulétekio Ave, 2054 Vilnius, Lithuania.

Graduated from Vilnius Civil Enginecring Institute (since 1990 Vilnius Technical University (VTU)) in 1984 obtaining a diploma of civil engineer. Being involved into research on multiple criteria analysis of agricultural production buildings he obtained PhD degree in 1990. He has been doing research at Aalborg University, Denmark in 1991 and at the University of Glamorgan, U.K. in 1993/1995. At present he is associate professor at VTU. He is an author and co-author of 3 monographs and more than 50 papers. Research interests: arc duc to theory of multiple criteria decision making, expert systems, total quality management, computer-aided design. 